Near the beginning of this book, Porter evokes our common fearful uncertainty by quoting the English fever specialist Thomas Sydenham: "How my soul, which I look upon to be an immortal Being in me, that is the Principle of thinking, should extinguish with my Body I cannot in any reasonable way of thinking conceive." By focusing on the implications of mortality, Porter courageously chooses an emotive theme which, for his readers, is rendered still more poignant by the knowledge that this is a posthumous publication. Although he had finished writing the text, this book sadly lacks endnotes and illustrations. As some compensation, Porter's magnificent last work does amply demonstrate that his own "principle of thinking" will live on to illuminate future generations.

Patricia Fara is a fellow of Clare College,

University of Cambridge,

Cambridge CB2 1TL, UK.

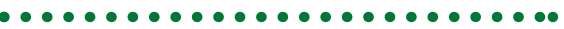

\section{A base in space}

\section{Leaving Earth: Space Stations, Rival Superpowers, and the Quest for Interplanetary Travel \\ by Robert Zimmerman \\ Joseph Henry Press: 2003. 528 pp. \\ $\$ 27.95, \mathfrak{E} 19.95$}

\section{Asif A. Siddiqi}

Ever since humans first dreamed of exploring the cosmos, the concept of the space station has stood at the forefront. Yet it was only in the early 1970s, nearly 15 years after the beginning of the space era, that both the Soviet Union and the United States launched their first modest space stations. The United States abandoned its impressive Skylab station in 1974, but the Soviets doggedly continued to build incrementally improved space stations of the Salyut series, until they discarded these to assemble the multimodular Mir space station in the late 1980s. These efforts were the forerunners of today's International Space Station (ISS), a continuously manned facility that has unfortunately inspired more headaches than hopes for future exploration.

In his substantial work Leaving Earth, Robert Zimmerman tells the story from the early missions of the Salyut and Skylab stations all the way to the current operations on the ISS. His focus is not on the science but on the human experience of developing and operating space stations and its attendant political context. He capably narrates stories of the numerous Soviet crews that visited the Salyut and Mir space stations in the 1970s and 1980s, an exercise that could have been repetitive and monotonous in less adept hands.

He engagingly describes how the Soviets gradually extended the endurance record in space - from a modest three months in $1977-78$ on the Salyut-6 station to a yearand-a-half in 1994-95 on board Mir - and how, in so doing, they gathered enormous experience in maintaining human life beyond Earth. We learn of incompatible crews, repair expeditions, psychological problems, failed visits to stations and innovative refuelling exercises - all part of a decades-long learning experiment.

Zimmerman shows how, as missions grew longer, Soviet crews became more selfreliant in fixing problems, and ground control became increasingly flexible in reacting to unforeseen situations. By contrast, in the 1980s and 1990s the Americans, who were flying relatively short space-shuttle missions, planned astronauts' activities down to the last minute, with little of the flexible planning that characterized the early ground-breaking Skylab of the early 1970s. As Zimmerman explains, these different approaches to mission planning were highlighted most starkly during the final eventful missions to Mir when Americans worked as guests aboard the Russian station. Yet by the end, the Russians had learned to respect the capabilities of US astronauts, who in turn acknowledged that their approach to mission planning was far from optimal.

The book works on a narrow level, as an engaging narrative of human experiences with longer and longer space missions. But as a whole, it is deeply flawed. Zimmerman's explanations of the political imperatives and implications of the Soviet and US space-station programmes are naive. The extraordinary claim that "the [Soviet] space program that the communists supported and funded in their futile effort to reshape human nature helped wean Russia away from communism and dictatorship and toward freedom and capitalism" is so absurd that it undercuts much of the value of the book. Most Russians who experienced the fall of the Soviet Union or who study such things would be surprised to learn that space flight had anything at all to do with their path to a democratic society and the ultimate disintegration of the communist empire.

Also out of place are Zimmerman's frequent digressions about Leonid Brezhnev's alleged interference with the Soviet space missions of the 1970s and early 1980s. Reliable revelations from the past ten years or so - all of which Zimmerman ignores seem to suggest exactly the opposite, that the Soviet space programme was not micromanaged at the topmost level.

Zimmerman also directs much vitriol against NASA, which he feels has lost direction since the halcyon days of the 1960s when it managed to accomplish such an extraordinary achievement as the Apollo Moon landings. Lamenting NASA's transformation into a topdown centralized bureaucracy that is incapable of innovation, he notes that "like ships passing in the night, the Russians have become freedom-loving capitalists, while the Americans have become control-loving freaks."

NASA deserves criticism for many things, but Zimmerman's conclusions betray his simplistic understanding of NASA during the Apollo years. As Walter McDougall has pointed out in The Heavens and the Earth (Johns Hopkins University Press, 1997), NASA won the Moon race for many reasons, but underlying the success was its functioning as a centralized, top-down bureaucracy with a single, highly politicized goal (to land on the Moon before the end of the decade) and a lot of money.

If Zimmerman's work is undone by his

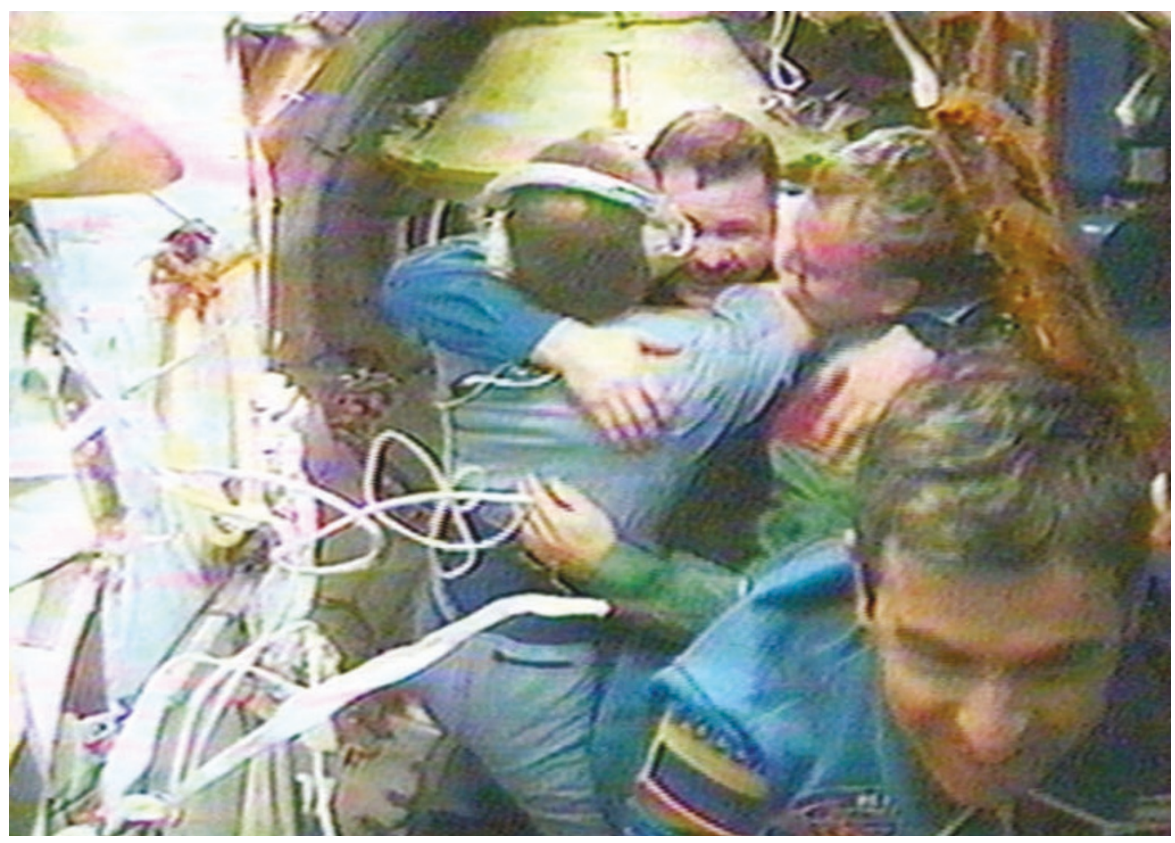

Warm welcome: new crew members arrive on MIR from Soyuz. 
forays into political history, his book is still useful as a narrative of human space exploration from the 1970s onwards. As such, it is best read piecemeal, skipping the bits on politics and following the story of the missions that extended the human capability to live in space.

Asif Siddiqi is in the Department of History,

Carnegie Mellon University, Pittsburgh,

Pennsylvania 15213, USA.

Website

Tempting teens with love in the lab

\section{Planet Jemma \\ www.planetjemma.com \\ Carina Dennis}

Lust, lip balm and science ... welcome to Planet Jemma! This new frontier is an Internet-based soap opera designed to get girls interested in physics. The online drama, which went live in February, orbits around Jemma, a 19-year-old first-year astrophysics student enrolled at a British university. Users track the hormonally laden and angst-ridden experiences of Jemma over 14 episodes - through her video diaries and e-mails - as she grapples with insecurities over physics classes, the temptations of an attractive egocentric colleague, and the expectations of her female mentor.

The drama is narrative-driven rather than being overtly science-based, and interactivity lies at its core. Users receive regular personalized e-mails from Jemma that are tailored to information provided by the user on registration and in response to quizzes, and they can correspond with Jemma via SMS text messages.

The website is targeted at 13-16-year-old girls, who are lured by routes outside the usual educational contexts, such as advertisements in teen magazines with offers of free lip balm on registration (although this offer has now ended). Its creators, Tim Wright and Rob Bevan of the online entertainment company XPT, wanted to create something that was different from formal science education programmes, "something outside the classroom that girls could relate to and felt was cool". But Jemma's charismatic qualities are likely to attract a wider audience, including members of the opposite sex.

Planet Jemma walks a delicate line between science and entertainment. The science is not obvious, mostly tucked away in Jemma's online notebook, and could readily be skipped by the uninterested visitor who just wants to know who Jemma will snog (British for 'neck'). But that may well be one of the strengths of the site - to create a

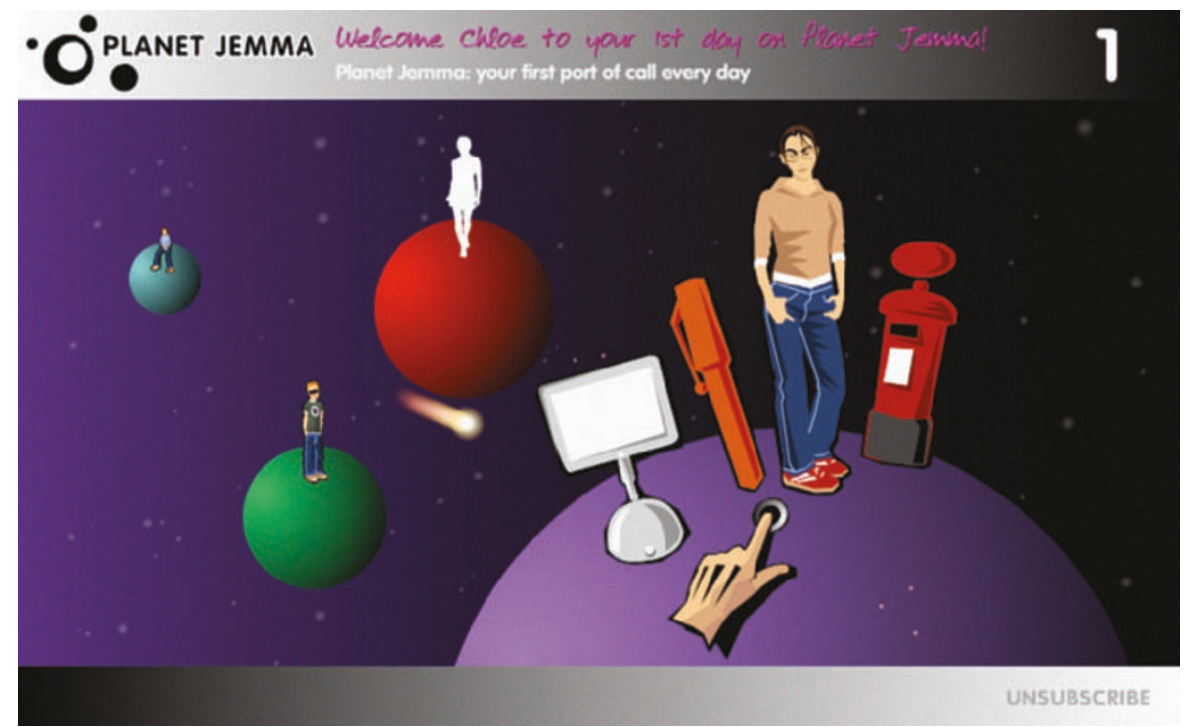

Soap science: turning teens on to physics.

context that teenage girls can relate to and then draw them into the science of black holes and antimatter.

The scientific information embedded in the crevices of the site is informative and interesting, and is crafted in an accessible format with links to other useful science sites. The most interesting, but perhaps overlooked, aspects of the site are the profiles of female scientists working in the physical sciences and their perspectives on science as a career.

Wright would like to extend the online relationship that girls have with Jemma to real-life undergraduates and research assistants at universities. "We could take them from a fictional world to an online mentoring system where they get to talk to real people doing real science", says Wright, although he acknowledges the difficulties of blurring fiction and reality.

Women may feel their hackles rise when Jemma encounters the sexism of her male peers, drops her jeans after a liquid-nitrogen spill and succumbs to drunken embarrassment over her unrequited affections. But there is solace in the fact that Jemma overcomes adversity, dumps the guy and sticks with her physics course in the quest to find a planet she can call her own.

Couched in the vernacular of British adolescents, the drama is unlikely to travel well. But versions tailored for audiences in different countries are likely to be just as successful.

Planet Jemma was created with a grant of $£ 90,000$ (US\$150,000) from the National Endowment for Science, Technology and the Arts, a British agency that supports scientific and cultural innovation and is funded by the national lottery. The website has attracted nearly 30,000 registrations, of which about $10 \%$ stick it out to the end. This doesn't sound like a lot but Wright and Bevan think that if just a few hundred of these girls decide to pursue science as a career then the project will have succeeded. ated by education experts, but Wright claims that more than half of the users that vote in the final episode say that the site improved their perception of studying science. At any rate, Planet Jemma may help to redress the imbalance of the male-dominated world of undergraduate physical-science courses. Carina Dennis is Nature's Australasian correspondent.

\section{New in Paperback}

The Road to Stockholm: Nobel Prizes, Science, and Scientists

by István Hargittai

Oxford University Press £9.99

The Blank Slate: The Modern Denial of Human Nature

by Steven Pinker

Penguin \$16 (US), \$24 (Canada)

"Pinker presents an overarching view of the world in a way that quite a few readers will find seductive". David Hull Nature 419, 251-252 (2002).

\section{Genetic Destinies}

by Peter Little

Oxford University Press £8.99

Sexual Selections: What We Can and Can't Learn About Sex From Animals

by Marlene Zuk

California University Press \$16.95, £10.95

Self-Organization in Biological Systems by Scott Camazine, Jean-Louis Deneubourg, Nigel R. Franks, James Sneyd, Guy Theraulaz and Eric Bonabeau

Princeton University Press $\$ 35, £ 22.95$
The website's impact has yet to be evalu- 